\title{
A CONSTRUÇÃO NARRATIVA EM TRÊES ESTÓRIAS DA TERRA, DE ERASMO LINHARES: O CASO DO NARRADOR ZECA-DAMA
}

\section{THE NARRATIVE CONSTRUCTION IN TRÊS ESTÓRIAS DA TERRA, BY ERASMO LINHARES: THE CASE OF THE NARRATOR ZECA-DAMA}

\author{
Ana Paula Cantarelli ${ }^{1}$
}

Recebido em: 31 mar. 2019

Aceito em: 17 jun. 2019.

DOI 10.26512/aguaviva.v4i2.23874

\begin{abstract}
RESUMO: Este estudo visa discutir a trilogia Três estórias da terra, integrante da obra $O$ tocador de charamela (1979), de autoria do amazonense Erasmo Linhares, a partir da análise do narrador Zeca-Dama. Para tal, encontra-se dividido em três parte. A primeira, Zeca-Dama: o contador de histórias, apresenta brevemente os textos que compõem a trilogia (Tio Antunes; Zeca-Dama; João Carioca: mandão e famão - juiz de paz). A segunda, O narrador ZecaDama: um contador de histórias contemporâneo, aborda a construção do narrador nos contos, analisando-a a partir de textos de autores como Benjamin (1994), Adorno (2003) e Ginzburg (2012). Por fim, a terceira parte, Zeca-Dama: um olhar sobre a Amazônia, a partir de estudos desenvolvidos por Silva (2008) e Santos (2018), discorre sobre a maneira como o narrador apresenta a natureza amazônica em contraposição com obras anteriormente produzidas sobre a região.
\end{abstract}

Palavras-Chave: Narrador; Zeca-Dama; Erasmo Linhares; Literatura Amazonense.

ABSTRACT: This study aims to discuss the trilogy Três estórias da terra, part of the book $O$ tocador de charamela (1979), written by the Amazonian author Erasmo Linhares, based on the analysis of the narrator Zeca-Dama. Therefore, it will be divided into three parts. The first one, called Zeca-Dama: o contador de histórias, briefly presents the texts that make up the trilogy (Tio Antunes, Zeca-Dama and João Carioca: mandão e famão - juiz de paz). The second part, O narrador Zeca-Dama: um contador de histórias contemporâneo, approaches the construction of the narrator in the short stories, by focusing on texts from the perspectives of some authors such as Benjamin (1994), Adorno (2003) and Ginzburg (2012). Finally, the third part, Zeca-

\footnotetext{
${ }^{1}$ Professora Adjunta da Universidade Federal de Rondônia (UNIR). Graduada em Letras - Português e Respectivas Literaturas e graduada em Letras - Espanhol e Respectivas Literaturas ambas pela Universidade Federal de Santa Maria (UFSM). Especialista em Linguagens, Códigos e suas Tecnologias, pelo Centro Universitário Internacional (UNINTER). Mestra em Letras pela Universidade Federal de Santa Maria e Doutorado em Letras, após um período sanduíche na Universidad de Guadalajara, no México. Atua na graduação e na pós-graduação na UNIR. E-mail: anapaula.cantarelli@gmail.com
} 
Dama: um olhar sobre a Amazônia, based on studies developed by Silva (2008) and Santos (2018), discusses how the narrator presents the Amazonian nature as opposed to the fiction previously produced on the region.

Keywords: Narrator; Zeca-Dama; Erasmo Linhares; Amazonian Literature.

\section{CONSIDERAÇÕES INICIAIS}

Erasmo do Amaral Linhares nasceu em Coari, um munícipio localizado no interior do Amazonas, no dia 02 de junho de 1934, e faleceu em Manaus, no dia 16 de outubro de 1999. Graduado em Comunicação pela Universidade Federal do Amazonas, sua formação permitiulhe acumular dois empregos: o cargo de professor, na instituição onde estudou, e a atuação como jornalista, dedicando-se, principalmente, ao radialismo. Ao longo de sua carreira, Linhares publicou diversas crônicas e contos nos jornais de Manaus, mas sua produção mais conhecida esteve atrelada à escrita diária de crônicas radiofônicas com temas de natureza política, social e econômica que chegavam ao público através de seus programas na Rádio Rio Mar.

Luís Ruas, no Prefácio da primeira edição de $O$ tocador de charamela, denominou Linhares como "Homem de Rádio", empregando letras maiúsculas para tal, com o intuito de diferenciá-lo do que ele chamou de "homens de rádio (no caso, vale a letra minúscula), que se apoderam de um microfone (deles mesmos ou de outros), para opiar ainda mais o povo" (RUAS, 1979, p. 11). De acordo com Ruas, o autor, através de seus programas radiofônicos, intentava ofertar um olhar crítico, permeado por um tom de denúncia (o que encontraremos também em seus textos literários) sobre a realidade da região, compondo "um binômio inseparável com a Rádio Rio Mar”, o qual se caracterizava "pelo esforço sincero de oferecer um serviço cuja meta principal é a valorização do homem amazônico" (RUAS, 1979, p. 12). Também Arthur Engrácio (1994, p. 44), na antologia Poetas e prosadores contemporâneos do Amazonas, apontou para a produção do autor amazonense destacando sua preocupação com o aspecto social: "as suas histórias destacam-se pelo humanismo de que se impregnam e sua tônica é sempre o sofrimento, a dor, a angústia, a miséria que envolve a criatura humana e a transformam em um objeto de nossa compaixão" (ENGRÁCIO, 1994, p. 44).

Ao longo de sua carreira, Erasmo Linhares publicou apenas dois livros de contos: $O$ tocador de charamela (1979) e O navio e outras estórias (1997). O primeiro, objeto deste estudo, é composto por duas trilogias - "O jogo de dados" (abrindo o livro) e Três estórias da 
terra (encerrando o livro) - e outras onze histórias (Os pássaros de gelo; O tocador de charamela; Doña Morales; Tampinha; Um homem importante; A construção da montanha; Arduene; A mura; A visita de primo Basílio; O comendador; A rede da solidão). Em nota do autor, antes de iniciar os contos, Linhares apresentou a definição da palavra charamela retirada do dicionário, para, a seguir, escolher um dentre os seus significados (VII. O mesmo que charanga [orquestra mais ou menos desafinada]) para servir como sentido ao livro (É neste último sentido o título do livro - LINHARES, 1979, p. 15). Ruas (1979, p. 14), no entanto, opõe-se a essa justificativa, argumentando que "O tocador de charamela, ao contrário, é um livro muito bem afinado". Concordamos com a proposição de Ruas de que a escolha de Linhares pelo título do livro e sua insinuação de que o conjunto da obra seria "desafinado" não reflete a organicidade e o conteúdo dos textos. Todavia, é preciso lembrar que, à época de sua publicação, $O$ tocador de charamela permaneceu alguns anos nas prateleiras, aguardando ser descoberto pela crítica. E, ainda hoje, cerca de quarenta anos após a sua publicação, parcos são os estudos que se dedicaram a analisar seu conteúdo, sendo, portanto, um dos objetivos deste texto contribuir com as discussões estabelecidas acerca da obra desse autor.

Para este trabalho foi selecionada a trilogia Três estórias da terra, a qual é composta pelos textos Tio Antunes, Zeca-Dama e João Carioca: mandão e famão - juiz de paz. Nosso intuito é promover uma discussão desses textos a partir da figura do narrador (Zeca-Dama) presente em todos eles. Zeca-Dama é um imigrante nordestino que veio para o Amazonas buscando, dentre outras coisas, ganhos financeiros. Sua voz narrativa atribui às histórias que conta um caráter próximo da oralidade, o que nos permite relacioná-lo às discussões estabelecidas por Benjamin (1994), nos textos Experiência e Pobreza e O narrador. Considerações sobre a obra de Nikolai Leskov, acerca do papel do contador de histórias da tradição oral. Em paralelo com essa relação está outra: a associação de Zeca-Dama às configurações do narrador contemporâneo na literatura brasileira.

Ambas podem ser vistas como complementárias neste estudo, uma vez que foi através das múltiplas possibilidades delineadas nas narrativas contemporâneas brasileiras que ZecaDama pôde assumir o papel de um contador de histórias, função essa já há muito tempo em desuso em nossa sociedade. Dessa forma, o presente estudo encontra-se dividido em três partes. A primeira, intitulada Zeca-Dama: o contador de histórias, apresenta um breve resumo dos contos que serão analisados, destacando as relações presentes entre eles. A segunda, O narrador Zeca-Dama: um contador de histórias contemporâneo, discute a construção da figura do narrador na trilogia Três estórias da terra, empregando como arcabouço teórico textos de 
Benjamin (1994), Adorno (2003) e Ginzburg (2012). A terceira e última parte, Zeca-Dama: um olhar sobre a Amazônia, a partir de estudos desenvolvidos por Silva (2008) e Santos (2018), aborda a forma como o narrador Zeca-Dama refere-se a aspectos da natureza amazonense nos três contos em comparação com obras anteriormente produzidas sobre a região.

\section{Zeca Dama: o contador de histórias}

Três estórias da terra é uma trilogia composta por textos curtos (Tio Antunes, ZecaDama e João Carioca: mandão e famão - juiz de paz), narrados pelo nordestino Zeca-Dama, um imigrante cearense pobre e homicida que veio para o Amazonas com o intento de fugir da polícia e de ganhar dinheiro. O título (Três estórias da terra) pode ser compreendido a partir do conteúdo dos contos, o qual versa sobre a rotina de trabalho nos seringais e nas áreas que estavam sendo desmatadas para a criação do gado, vinculando, temporalmente, as narrativas ao final do século XIX e início do século XX, no cenário amazonense. A linguagem simples, permeada pelo emprego de regionalismos, atrela o narrador ao falar do povo amazônico, o que, entre outros fatores, confere às histórias o caráter de um "causo" contado por alguém que vivenciou a realidade de trabalho e de exploração do Amazonas. Além do narrador, vale ainda destacar que o conteúdo dos textos permite que os relacionemos entre si. A temática do isolamento, da solidão em meio ao Amazonas, da escassez de mulheres e do trabalho exploratório, escravizante, repetem-se em todos os contos, ampliando suas significações.

Se estabelecêssemos uma ordem cronológica, os contos ficariam assim organizados: Zeca-Dama, no qual o narrador fala de sua chegada e adaptação ao Amazonas; João Carioca: mandão e famão - juiz de paz, no qual, ainda nos seringais, fala da distribuição de mulheres como prêmios pelo trabalho dos homens e relata sobre o casamento de Pedrão e, por fim, Tio Antunes, no qual Zeca-Dama e Pedrão encontram-se já trabalhando com a derrubada da floresta para a criação de gado. No entanto, optamos por apresentar os textos na ordem em que eles figuram no livro.

O primeiro conto, Tio Antunes, tem como protagonista Antunes, ao redor de quem há uma aura de mistério. Zeca-Dama compartilha conosco as poucas informações que sabe: "constava que ele já tinha sido casado, no tempo do mata-onça, no Aripuanã. A mulher, uma velha mura feiticeira, morta na peste de varíola. Mas dela ele nunca falava. Fazia segredo" (LINHARES, 1979, p. 95). O espaço no qual a narrativa se desenvolve é o interior do Amazonas, em uma zona de floresta que está sendo derrubada para abrir espaço para a 
agropecuária. Os homens que iniciam o conto (seis ao todo, incluindo o narrador e o protagonista) trabalham de sol a sol em um regime de exploração da mão-de-obra que beira a escravidão. No trabalho que desenvolviam, tio Antunes era o chefe, embora nenhum dos empregados soubesse exatamente quem era o contratante: "Tio Antunes era o chefe, a mando da companhia. Só companhia, porque o nome todo a gente não sabia não" (LINHARES, 1979, p. 95).

Dentre os seis, apenas um homem, o Pedrão, tem uma esposa. Os demais tinham "valência nas bananeiras", exceto tio Antunes que "não queria saber daquilo. Porcalhada, dizia" (LINHARES, 1979, p. 95). Junto com os bois para os quais o terreno vinha sendo preparado, chegaram mais quatro peões cearenses e um gaúcho, além de um gerente e sua esposa. A chegada de uma mulher desestabilizou tio Antunes, fazendo-o buscar na bebida uma forma de evasão. Num domingo de sol, o gerente e sua mulher vestiram trajes de banho para entrar no rio. Os homens fixaram os olhos na mulher. Tio Antunes, por sua vez, ao deparar-se com tal visão, levantou do banco onde se encontrava: "Jesus, disse bem alto" (LINHARES, 1979, p. 97) e correu para a beira do rio, onde permaneceu durante algum tempo, para, então, retornar ao barracão, sendo seguido pelo narrador e por Pedrão: “Abriu a mala grande que nunca abria, remexeu uns panos e do fundo tirou um vestido branco comprido e um retrato velho, e, com a faca de migar tabaco, começou a estraçalhar tudo" (LINHARES, 1979, p. 97). A seguir, sentouse e começou a chorar. Dias depois, quando veio o motor, tio Antunes foi embora. E, apesar o gerente dizer que foi doideira de cachaça, Zeca-Dama afirma que foi "doideira de mulher" e que todos lá acabariam assim.

O segundo texto, Zeca-Dama, traz a figura de um interlocutor a quem o narradorprotagonista se dirige com frases como: "Não, senhor, desarme essa cara de malícia. Não é nada do que o senhor está pensando" (LINHARES, 1979, p. 101) e "Peço que não duvide de mim" (LINHARES, 1979, p. 107), enquanto conta a origem de seu apelido - tal figura também estará presente no terceiro conto. O narrador-protagonista, ao início do texto, apresenta sua origem (cearense) e informa que, da mesma forma que ele, outros tantos nordestinos vieram para o Amazonas com a ideia de conseguir dinheiro. No seu caso em particular, ele ainda destaca que viajou fugido da polícia, após ter assassinado um homem no sertão devido a uma briga por terras. A descrição sobre como ocorreu sua chegada no Amazonas permite uma relação com a forma como os negros escravizados na África eram trazidos nos porões dos navios para o Brasil, relacionando o transporte e, mais à frente, o trabalho desse grupo de imigrantes com uma nova forma de escravidão, a qual já havia sido mencionada pelo narrador no conto anterior. 
A chegada ao Amazonas, ao contrário do que se esperava, não abrandou os obstáculos encontrados na travessia. Confinados em pequenos espaços e submetidos à ausência de condições de higiene, os sujeitos são animalizados. Após dois meses em uma hospedaria, ZecaDama foi mandado para trabalhar nos seringais: "Duro, meu senhor, duro foi acostumar naquele mundão de mato vazio de gente e com a doideira daquele trabalho de escravo" (LINHARES, 1979, p. 102). O narrador relata que, com o passar do tempo, resignou-se ao local e ao trabalho, estabelecendo amizade com um seringueiro amazonense de nome Dorca.

Os sábados são apresentados como um dia de folga na escravizante rotina de trabalho. Nesses dias, os seringueiros iam às festas na casa de Mestre Felisberto. Lá encontravam música, mas não havia mulheres com quem dançar. Então, dançava-se homem com homem. O narrador, no intento de agradar a Dorca, aceita fazer as vezes de mulher no salão de baile. Sua aptidão para a dança rendeu-lhe o apelido que intitula o conto: Zeca-Dama. Embora durante o texto, por diversas vezes, faça questão de frisar sua masculinidade, negando-se inclusive a vestir-se como mulher quando um de seus companheiros o sugere, Zeca-Dama encerra o conto enaltecendo seus dotes de dançarino e afirmando que nenhuma mulher das que habita, hoje, a região, dança melhor do que ele dançava.

O terceiro e último conto, João Carioca: mandão e famão - juiz de paz, traz como personagem principal João Carioca, o qual "era o homem mais rico de todas essas bandas. [...] Poderoso, meu senhor, muito poderoso. Podre de rico, mandão e famão, até com gente da capital" (LINHARES, 1979, p. 107). Zeca-Dama trabalhou nos seringais dez anos para o protagonista. Após as linhas iniciais em que apresenta João Carioca, mais uma vez o narrador retoma o tema da ausência de mulheres: "Já lhe contei uma vez, mulher por aqui não havia de começo. Coisa muito rara e por causa disso os homens endoidavam" (LINHARES, 1979, p. 108). João Carioca, ciente da falta de mulheres, transformava-as em prêmios, os quais eram concedidos aos seringueiros por sua dedicação ao trabalho: “Trabalhou, ele arranjava mulher, mas obrigava a casar e quando os filhos nasciam, ele trazia o padre de Rio Branco, espichando viagem de semanas, só para batizar os moleques. E João Carioca era o padrinho" (LINHARES, 1979, p. 108). Trazidas de prostíbulos no Nordeste brasileiro, elas eram distribuídas de acordo com o trabalho do seringueiro: quanto maior a quantidade de borracha produzida, maior a beleza da mulher concedida.

Quando nomeado juiz de paz, João Carioca celebrou a união de todos os casais que ele formou. Os casamentos ocorriam coletivamente nos sábados à tarde. Num desses sábados, chegou Daniel, um sujeito mirrado, acompanhado de sua noiva, muito maior que ele, e o Pedrão, 
um homenzarrão, acompanhado de uma mulher pequena, se comparado com o tamanho do noivo. João Carioca, percebendo o equívoco que cometera na hora de distribuir as noivas, mandou os casais trocarem de par: “Troca, gritou. Ninguém entendeu. Troca, berrou. É como vai dar certo e é pro bem de todo mundo. Não quero ver ninguém morrendo nestas bandas. E trocaram e deu certo" (LINHARES, 1979, p. 110).

\section{O narrador Zeca-Dama: um contador de histórias contemporâneo}

O narrador Zeca-Dama, responsável por guiar o leitor através dos contos que compõem Três estórias da terra, apresenta uma constituição bastante particular. Primeiramente, por sua origem, enquanto nordestino pobre e migrante, sua voz destoa da que convencionalmente, durante muito tempo, instituiu-se, no cenário brasileiro, como voz narrativa. E, em segundo lugar, porque a forma como os textos são apresentados encontra pontos de similaridade com os contadores de história da tradição oral, figuras essas que deixaram de existir devido a alterações nas configurações sociais. Tal constituição, embora possa parecer contraditória inicialmente, propõe o resgate e a valorização de uma forma de narrar, já em desuso, através do rompimento com uma tradição literária instaurada, a qual negava voz e vez a determinados segmentos populacionais. Para melhor compreender como Zeca-Dama estrutura-se, vejamos como ele aproxima-se do contador de histórias e como ele distancia-se do modelo de narrador erigido pela tradição.

O filósofo alemão Walter Benjamin, em vários de seus textos, discutiu a transmissão oral de experiências de uma comunidade, de maneira modelar, através das gerações, destacando a figura do contador de histórias. Dentre seus escritos, dois mostram-se particularmente úteis para abordar este tema a partir dos objetivos deste estudo: "Experiência e pobreza", datado de 1933, e O Narrador: considerações sobre a obra de Nikolai Leskov, de $1936^{2}$. No primeiro, Benjamin discorre sobre a figura do contador de histórias da tradição oral ${ }^{3}$, a qual, segundo ele, encontrava-se em declínio. Os motivos apresentados para justificar tal afirmação estão atrelados à comunicabilidade da experiência.

\footnotetext{
${ }^{2}$ Com apenas três anos de diferença, ambos os textos apresentam tamanha proximidade temática entre si que compartilham não apenas ideias, mas também estruturas argumentativas e, em algumas passagens, é possível encontrar trechos com conteúdo praticamente idêntico, o que possibilita que os empreguemos em conjunto.

${ }^{3}$ Nas traduções feitas para o português da obra benjaminiana, optou-se, majoritariamente, pelo uso do termo "narrador" para referir-se à figura do contador de histórias, levando muitos estudiosos das obras do filósofo alemão a confundirem-no com a categoria literária do narrador, o que gerou uma série de equívocos interpretativos.
} 
De acordo com o filósofo, a experiência sempre fora comunicada aos jovens como fonte de saber, através da memória: "de forma concisa, com a autoridade da velhice, em provérbios; de forma prolixa, com a sua loquacidade, em histórias; muitas vezes como narrativas de países longínquos, diante da lareira, contadas a pais e netos" (BENJAMIN, 1994, p. 114). No entanto, devido às mudanças sociais desencadeadas pela evolução das forças produtivas impulsionadas, principalmente, pela Modernidade, as narrativas deixaram de conter experiências modelares, o que passou a impossibilitar a sua transmissão através do tempo: "nunca houve experiências mais radicalmente desmoralizadas que a experiência estratégica pela guerra de trincheiras, a experiência econômica pela inflação, a experiência do corpo pela fome, a experiência moral pelos governantes" (BENJAMIN, 1994, p. 115). Em virtude disso, a figura do contator de histórias deixou de ocupar um lugar na sociedade, sobretudo após a Primeira Guerra Mundial, quando os homens retornaram nos campos de batalhas "mais pobres em experiências comunicáveis" (BENJAMIN, 1994, p. 115).

O segundo texto, O Narrador: considerações sobre a obra de Nikolai Leskov, inicia de forma similar ao primeiro, reconhecendo que "a arte de narrar está em vias de extinção", sendo “cada vez mais raras as pessoas que sabem narrar devidamente" (BENJAMIN, 1994, p. 197).

Com o andar do texto, Benjamin divide os contadores de história em dois grupos, que se interpenetram de múltiplas maneiras, cujos representantes arcaicos seriam: os narradores que muito viajam, que vem de longe, e conhecem muito do mundo, sintetizados como "marinheiros comerciantes" e aqueles que ganharam a vida honestamente sem sair de seus países e que conhecem suas histórias e tradições, denominados como “camponeses sedentários". Sobre essas duas classes, ele ainda complementa: "se os camponeses e os marujos foram os primeiros mestres da arte de narrar, foram os artífices que a aperfeiçoaram. No sistema corporativo associava-se o saber das terras distantes, trazidos para casa pelos migrantes, com o saber do passado, recolhido pelo trabalhador sedentário" (BENJAMIN, 1994, p. 199).

A partir das considerações tecidas por Benjamin acerca do contador de histórias da tradição oral, é possível associar aspectos da construção de Zeca-Dama a essa figura, dentre os quais vale a pena destacar: a presença de um interlocutor, o caráter migrante do narrador, o fato de ele ser partícipe das experiências que narra e o contexto espacial e temporal no qual as ações acontecem. Em relação ao primeiro, a presença de um interlocutor nos textos, cuja identidade desconhecemos, sendo denominado de "senhor" pelo narrador-personagem, cria a figura de um ouvinte, a qual é reforçada por uma constante interpelação estabelecida por frases como: "Mas lhe digo que já fui dama afamada" (LINHARES, 1979, p. 101); "Um horror, meu senhor, uma 
coisa muito triste de ser lembrada" (LINHARES, 1979, p. 101). Tal construção promove um vínculo entre o texto escrito e a narrativa oral e, por conseguinte, entre o narrador dos contos e o contador de histórias, levando o leitor a aproximar-se do ouvinte e, em alguns momentos, aceitar que Zeca-Dama está dirigindo-se diretamente a ele, como faziam os contadores de história.

Na condição de imigrante cearense que, ao chegar ao Amazonas, vive em diversos lugares, mudando-se de acordo com as oportunidades de trabalho, Zeca-Dama poderia ser associado a um narrador viajante (atrelado ao "marinheiro comerciante", de Benjamin), pois muito já conheceu e viveu. Por ser personagem de seus relatos, o que ele conta provém de suas experiências, ora focalizando o relato sobre si próprio, ora posicionando-se como observador e partícipe, elegendo as vivências de outros como centro da narração. Seu conhecimento de mundo é apresentado como um conjunto de experiências que é transmitido através do tempo. E, embora a temática principal sobre a qual os textos versam seja a falta de mulheres na região - problema este já resolvido no momento em que os relatos ocorrem -, a sua experiência adaptativa, a sua persistência e as situações ocorridas com seus companheiros podem ser tidas, sob determinados aspectos, como modelares para os seus ouvintes.

Também o título da trilogia, ao trazer a palavra "estórias", remete à narrativa popular, ao conto tradicional, ao ato de narrar experiências que se particularizam frente às que compõem a história dita oficial. Zeca-Dama apresenta três estórias, três causos, e, embora cada uma traga como título o nome de um indivíduo singular, elas se desenvolvem baseadas em experiências comunitárias. Por exemplo, em Tio Antunes, ao retratar a loucura do chefe, o narrador conta sobre a rotina de trabalho à qual ele e seu grupo estavam submetidos, permitindo que os relatos deixem de pertencer a um só indivíduo, atrelando-os a um grupo.

Sob o aspecto espacial e temporal, o meio rural no qual o narrador e os personagens estão inseridos, o tipo de trabalho desenvolvido (mais próximo do artesanal do que do industrial), as formas como os deslocamentos ocorrem, o momento histórico em que os textos se desenvolvem (início do século XX), relacionam-se com um período em que a industrialização ainda não havia alcançado a região Norte brasileira. Tais aspectos situam ZecaDama em um tempo e em um local antes da perda das experiências comunicáveis como modelares, o que reforçaria a sua configuração como um contador de histórias.

Ainda sobre os textos de Benjamin, neles, o filósofo aponta para a substituição da figura do contador de histórias por outras formas narrativas, destacando o romance e a informação jornalística, os quais surgem atrelados ao formato escrito (não mais oral) e, por conseguinte, 
impresso. No caso do romance, entre os seus elementos, destaca-se a figura do narrador, a qual é permeada pelo individualismo imperante na sociedade capitalista, distanciando-se do fator social integrante do ato de contar histórias e compartilhar experiências. Há uma substituição da experiência considerada como modelar pela vivenciada pelo indivíduo solitário. Sobre esse processo, no tex to O Narrador: considerações sobre a obra de Nikolai Leskov, Benjamin (1994, p. 201) afirma:

O primeiro indício da evolução que vai culminar na morte da narrativa é o surgimento do romance no início do período moderno. O que separa o romance da narrativa (e da epopeia no sentido estrito) é que ele está essencialmente vinculado ao livro. A difusão do romance só se torna possível com a invenção da imprensa. A tradição oral, patrimônio da poesia épica, tem uma natureza fundamentalmente distinta da que caracteriza o romance. O que distingue o romance de todas as outras formas de prosa - contos de fadas, lendas e mesmo novelas - é que ele nem procede da tradição oral nem a alimenta. Ele se distingue, especialmente, da narrativa. O narrador retira da experiência o que ele conta: sua própria experiência ou a relatada pelos outros. E incorpora as coisas narradas à experiência dos seus ouvintes. O romancista segrega-se. A origem do romance é o indivíduo isolado, que não pode mais falar exemplarmente sobre suas preocupações mais importantes e que não recebe conselhos nem sabe dá-los.

O isolamento, destacado por Benjamin como um dos traços definidores do romance, diferenciando-o das narrativas perpetuadas pelos contadores de história que visavam o coletivo, é um reflexo das configurações sociais instauradas, ou seja, os modos de narrar adaptam-se às mudanças experienciadas em cada período histórico. Da mesma forma que o romance necessitou da imprensa para ser difundido e comercializado, antes dele as narrativas orais exigiam o senso de comunidade e de perpetuação de experiências para que a figura do contador de histórias tivesse um papel social relevante. Sob esse aspecto, é de se esperar que a forma de narrar do romance também viesse a enfrentar alterações provenientes das mudanças sociais, pois, conforme Scholes e Kellog (1977, p. 47), "toda época e cultura têm suas formas narrativas".

No ano de 1954, chegou ao público o ensaio "A posição do narrador no romance contemporâneo" 4 , no qual Theodor Adorno discorreu sobre o ato de narrar frente a eventos catastróficos, como a Segunda Guerra Mundial. No texto, o filósofo apresentou o realismo como uma das marcas imanentes do romance. No entanto, face aos eventos desastrosos

\footnotetext{
4 “A posição do narrador no romance contemporâneo" foi publicada, em 1954, na revista Akzente [Acentos], n. 05. Em 1958, integrou a primeira edição de Notas sobre Literatura.
} 
ocorridos, que promoveram a desintegração não só da identidade da experiência, mas também da estrutura da vida em sociedade como concebida anteriormente, o emprego do realismo para a construção das narrativas literárias tornou-se questionável, estabelecendo um paradoxo: "não se pode mais narrar, embora a forma do romance exija a narração" (ADORNO, 2003, p. 55).

Como em uma sociedade capitalista, individualista, competitiva, violenta, que vivenciou o Holocausto, o ato de narrar pode recorrer ao real? O imperativo de contar, apesar da dor vivenciada, criou a necessidade do delineamento de outros tipos de formas narrativas, de outros tipos de narradores. Assim, no ensaio mencionado, Adorno (2003, p. 57) afirma: "Se o romance quiser permanecer fiel à sua herança realista e dizer como realmente as coisas são, então ele precisa renunciar a um realismo que, na medida em que reproduz a fachada, apenas a auxilia na produção do engodo".

No cenário brasileiro, Jaime Ginzburg (2012), no artigo O narrador na literatura brasileira contemporânea, empregando obras literárias produzidas a partir de 1960 até o momento em que elaborou seu texto, defendeu a ideia de que os desafios da contemporaneidade realizaram uma mudança nos valores estéticos canônicos e nas teorias consagradas sobre o narrador. O pesquisador aponta para uma tradição literária, correspondente aos valores da cultura patriarcal, cujo modelo priorizava "homens brancos, de classe média ou alta, adeptos de uma religião legitimada socialmente, heterossexuais, adultos e aptos a dar ordens e sustentar regras" (GINZBURG, 2012, p. 200).

Nesse sentido, na mesma linha argumentativa de Ginzburg, está o texto "Uma voz ao sol: representação e legitimidade na narrativa brasileira contemporânea", no qual Regina Dalcastagnè (2002) indicou a ausência, tradicionalmente, na literatura brasileira de classes populares, a qual se estende entre autores, personagens e narradores. Essa ausência, segundo ela, não se limita ao campo literário: “As classes populares possuem menor capacidade de acesso a todas as esferas de produção discursiva: estão subrepresentadas no parlamento (e na política como um todo), na mídia, no ambiente acadêmico. O que não é uma coincidência, mas um índice poderoso de sua subalternidade" (DALCASTAGNÈ, 2002, p. 35).

A prosa contemporânea, no entanto, tende a se distanciar dessa tradição, optando por “elementos narrativos contrários ou alheios à tradição patriarcal brasileira. [...] Trata-se de um desrecalque histórico, de uma atribuição de voz a sujeitos tradicionalmente ignorados ou silenciados" (GINZBURG, 2012, p. 200). Ginzburg (2012) considera essas novas construções narrativas como reelaborações da história a partir de perspectivas não hegemônicas, não dominantes. Segundo ele, "trata-se de falar, narrar, em condições que nunca foram possíveis, e 
interpretar o país a partir de horizontes historicamente condenados à mudez. Grupos sociais historicamente oprimidos elaboram, em novos autores, em narradores ficcionais, as condições para a presença dos excluídos” (GINZBURG, 2012, p. 203).

Em virtude da assunção da voz narrativa por parte de grupos que, durante muito tempo, permaneceram à margem da sociedade, é possível inferir a inexistência de um formato literário único, de maior valor, que se sobreponha aos demais, uma vez que a própria cena literária tem vivenciado um processo de reconfiguração de lugares e formatos. Dessa forma, segundo Piccinin (2012, p. 77): “A partir do surgimento de novas formas narrativas, advindas de suportes também originais e em coexistência com as já tradicionais formas, as narrativas contemporâneas vão instaurando uma ambiência marcada pela multiplicidade de formatos e conteúdo".

Sob esse prisma, Zeca-Dama pode ser considerado como um exemplo dos narradores que integram a prosa contemporânea. Nascido em uma região pobre e atormentada pela seca, oriundo de uma classe econômica baixa, homicida, foragido da polícia, trabalhando em um regime de escravidão, embrenhado na Floresta Amazônica, vivendo quase em solidão, sem mulheres, com poucos amigos, fazendo as vezes de mulher nas festas com os companheiros de trabalho, ele distancia-se do modelo de narrador tradicional destacado Ginzburg como imperante na narrativa brasileira antes de 1960, aproximando-se do contador de histórias da tradição oral ao relatar suas experiências, mas sem coincidir completamente com ele uma vez que sua voz oferece um ponto de vista dissociativo. De acordo com Santos (2018, p. 201), com a construção desse narrador,

Erasmo Linhares toma o partido dos oprimidos, criando assim um lugar de fala para os explorados dos seringais da Amazônia. Ou seja, ele assume a função do escritor contemporâneo que é a de denunciar os problemas sociais, políticos econômicos, a migração, trabalho escravo, opressão, animalização do homem, utilização da mulher como "prêmio", em decorrência do processo extrativista que se efetivou na Amazônia no século XIX e, retomado na década de 30 do século $\mathrm{XX}$, em que milhares de mulheres e homens livres trabalhavam para se escravizar.

Zeca-Dama, como parte de um grupo silenciado historicamente, não visa uma unidade social e estética. Ao contrário, com seu relato simples, próximo do contador de histórias, o que ele oferece e coloca em evidência é a experiência de um grupo social, em um período histórico e um contexto geográfico específicos. Dentro das experiências relatadas, há uma ênfase sobre a criatividade adaptativa que permite a ampliação das relações interpessoais, sobrepondo-se às 
dificuldades impostas pelo contexto experienciado. O próprio ato transgressor de vestir-se de mulher pode ser tomado como um exemplo de uma tentativa de adaptação à ausência feminina imposta pelo isolamento da região, o que desencadeou a loucura de diversos homens, como foi o caso de tio Antunes, protagonista do primeiro texto da trilogia. Também as festas dos sábados, com música e dança, podem ser tomadas como estratégias para encontrar um momento de prazer em meio ao trabalho escravo, possibilitando aos homens válvulas de escape frente à rotina massacrante.

O emprego da primeira pessoa permite que Zeca-Dama realize o seu relato sem mediações, identificando-o como experienciador da matéria que narra, o que lhe confere autoridade sobre o que conta. No entanto, percebe-se que há uma preocupação constante em afirmar que o conteúdo de suas histórias realmente é verdade, pois sua classe social e seu aspecto iletrado colocam-no em descrédito frente à figura do tradicional narrador branco de classe média ou alta: "Dou-lhe minha palavra" (LINHARES, 1979, p. 103); "Não pense que conto potoca. Já lhe disse que não sou homem disso" (LINHARES, 1979, p. 110). Os contos, por vezes, assumem um tom confessional e de denúncia, fazendo o cearense, em alguns momentos, verter lágrimas enquanto compartilha seus relatos: "Desculpe se esses olhos depois de velhos deram para chorar, mas aqui no fundo do peito ainda dói uma querença" (LINHARES, 1979, p. 101). Sob esse aspecto, Zeca-Dama assume um caráter de resistência por dar voz a um grupo sofrido e escravizado, através do resgate de um formato de narração já há muito tempo em desuso, o do contador de histórias.

\section{Zeca-Dama: um olhar sobre a Amazônia}

Alisson Marcos Leão da Silva (2008), na tese intitulada Representações da natureza na ficção amazonense, identificou e examinou imagens da natureza presentes na produção literária do estado do Amazonas, considerando a existência de uma tradição. Em um primeiro momento, seu estudo destacou três textos que, segundo ele, influenciaram os ficcionistas amazonenses: Inferno verde, de Alberto Rangel, e seu prefácio, escrito por Euclides da Cunha, e A selva, de Ferreira de Castro. Ao analisar as representações da natureza nessas obras e as suas recepções por parte dos intelectuais da área, Silva defendeu a constituição de uma tradição literária na forma como a natureza era representada até meados do século XX.

Tal tradição estabelecia um modelo no qual a floresta ocupava um lugar central frente à ação humana: "o privilégio que a descrição da natureza tivera naquelas narrativas não se 
sustenta apenas pela ênfase dada aos quadros naturais, mas também pelo enfraquecimento do humano, quando este é o elemento a ser retratado" (SILVA, 2008, p. 152). Segundo Silva (2008, p. 152), "mesmo em textos de preocupações abertamente humanitárias, [...] a representação do humano prioriza de tal maneira o aspecto social que os personagens perdem corpo; tudo o que vemos deles, ou que somos levados a ver, diz respeito aos temas da exploração". A seguir, o pesquisador voltou-se para o que ele denominou de "reprocessamento" dessa tradição, o qual, de acordo com sua tese, foi executado por três prosadores amazonenses (Arthur Engrácio, Astrid Cabral e Erasmo Linhares - todos integrantes do Clube da Madrugada ${ }^{5}$ ) entre as décadas de 1950 e 1980, conferindo novas roupagens ao tom narrativo e à questão da natureza no contexto amazonense e desconstruindo a representação delineada a partir do desconhecido, do ameaçador.

Considerar a existência de uma tradição literária de representação da natureza a qual foi revista a partir da escrita de Erasmo Linhares (entre outros autores) confere uma grande relevância à produção desse autor. O pesquisador defende que Linhares, em Três estórias da terra, promoveu um reprocessamento através, primeiramente, da leveza dos contos ("a começar pelo termo “estórias" do título, que dá a aparência de 'causo', muito distante da narrativa realista obcecada por algo bem maior que a verossimilhança: o documento" - SILVA, 2008, p. 174), que é proporcionada através do humor empregado na construção textual. O humor contrasta com as narrativas tradicionalmente produzidas sobre a região, nas quais a linguagem grandiloquente, pesada e trágica estava associada a uma tentativa realista de produção documental.

Para Silva (2008, p. 174), as histórias contadas por Zeca-Dama carnavalizam a temática da falta de mulheres, carnavalizando, por extensão, "todo o cenário: a dureza da realidade e a própria literatura que assim a representava". Como resultado dessa construção textual, está a ênfase no aspecto relativo da percepção da realidade, enfraquecendo, por conseguinte, o comprometimento do texto com o realismo, o qual era objetivado pela produção anterior. Segundo o estudioso, o olhar de Linhares está atento aos detalhes da cultura, à forma como se desenvolvem as interações humanas no Amazonas, adotando um tom diminuído frente à natureza, distanciando-se da perspectiva selvática e indomável e, por conseguinte, da forma como a região foi retratada literariamente até a metade do século XX. Em virtude disso, Zeca-

\footnotetext{
${ }^{5}$ O Clube da Madrugada foi uma associação artístico-literária, fundada na década de 1950, em Manaus, a qual congregou diversos intelectuais com a intenção de discutir e rever as práticas estéticas, sociológicas e políticas que vigoravam no Amazonas daquela época.
} 
Dama apresenta nos contos (principalmente em Tio Antunes) uma natureza domesticada, na qual o capim substituiu as matas e o gado ocupou o lugar dos animais selvagens: "a representação da natureza que perdurava no contexto amazonense vê questionados tanto o caráter de peso e sisudez que a constituíam [...], quanto o paradigma realista que a estruturava" (SILVA, 2008, p. 180-181).

José Benedito do Santos (2018, p. 199), no texto "Uma leitura de 'Três estórias da terra', de Erasmo Linhares", também aponta para a produção literária de Linhares como um rompimento frente à literatura amazonense produzida até o século XX:

[...] em "Três estórias da terra" tem-se a expressão de uma realidade, a qual evidencia a exploração de recursos naturais em contraponto com a miséria, violência, exploração do homem pelo homem. Por essa razão, estas estórias se apoiam em temas mais urgentes e distanciam-se da nossa produção literária voltada para a exaltação da natureza, pequenez do ser humano, a dicotomia oprimido $\mathrm{X}$ opressor que prevaleceu, a partir da segunda metade do século XIX até a primeira metade do século XX, nas narrativas amazonenses que retratam a migração nordestina e o ciclo da borracha.

Na leitura proposta por Santos, Três estórias da terra configura-se como uma forma de superar paradigmas, pois, ao empregar Zeca-Dama como narrador, Linhares "rompe com a tradição realista, naturalista, infernista e selvagem que permeou a literatura escrita sobre e na Amazônia", na qual "um narrador na terceira pessoa retratava os amazônidas, os seringueiros, nordestinos, (i)migrantes, como personagens emudecias, silenciadas e invisíveis, desaguando na tese de que todos eram propensos a morrer nas mãos de seus opressores" (SANTOS, 2018, 200).

Tanto os estudos promovidos por Santos (2018) quanto os propostos por Silva (2008) apontam para uma revisão da tradição promovida pela trilogia Três estórias a terra, de Erasmo Linhares, embora seus argumentos sejam diferentes. Silva destaca o caráter linguístico, manifestado através do humor que conduz a uma carnavalização da representação da realidade amazonense, e a ênfase sobre os aspectos da cultura como responsáveis por efetuar o reprocessamento da forma como a natureza amazônica era representada literariamente até meados do século XX. Já Santos aponta para o fato de ser o narrador Zeca-Dama, por sua constituição em primeira pessoa e por sua origem pobre, migrante, marginalizada, o encarregado de realizar tal rompimento. Esses argumentos podem ser vistos como complementares uma vez que a leveza linguística e o foco nos aspectos culturais somente são possíveis através da construção de um narrador como Zeca-Dama. No entanto, o que queremos 
acentuar, e que parece ter assumido um caráter secundário nos dois estudos mencionados, é o fato de que a constituição de Zeca-Dama como narrador, bem como o conteúdo de suas estórias somente são instituídos da forma como o foram devido a uma mudança nos valores estéticos canônicos e nas teorias consagradas ocorrida na literatura brasileira contemporânea.

Conforme foi possível ver na seção anterior, Zeca-Dama é um exemplo das novas construções narrativas que têm se delineado na literatura brasileira desde 1960 até o presente, as quais, dentre suas diversas marcas, trazem a reelaboração da história a partir de relatos heterogêneos de classes não dominantes. A literatura brasileira contemporânea, como pontuou Ginzburg (2012), abandonou o narrador guiado por uma tradição que correspondia aos valores da cultura patriarcal, para conferir voz a outros sujeitos, como é o caso de Zeca-Dama. Se na tradição literária de representação da natureza amazonense não se esperava que um nordestino pobre fosse o narrador das histórias, foi devido às alterações promovidas na literatura no cenário nacional que Zeca-Dama pôde, então, fazê-lo.

O narrador de Três estórias da terra não se interessa em narrar pelos velhos moldes (os quais também não possuem mais serventia) dos quais ele e a literatura já se libertaram, o que faz com que o reprocessamento da tradição, destacados por Silva (2008) e Santos (2018), ocorra, pincipalmente, pela liberdade de formas assumidas na literatura nacional e pelo reconhecimento que a voz de um sujeito como Zeca-Dama possui no momento em que conta suas estórias, convertendo o conteúdo destas em algo pertinente para os leitores.

Dessa forma, o reprocessamentos da tradição literária amazonense, atribuído por Silva (2008) e Santos (2018) aos textos de Erasmo Linhares, deve ser visto não como um fato isolado e motivado apenas por um repensar das formas como a natureza amazonense vinha sendo representada dentro da literatura produzida no estado (sendo esse um dos objetivos do Clube da Madrugada, do qual Linhares fez parte), mas sim como um movimento maior, desenvolvido em escala nacional. Sob essa perspectiva, o discurso de Zeca-Dama pode continuar a ser empregado como um dos reprocessadores da tradição de representação literária imperante na literatura amazonense, mas também precisa ser pensado em sua articulação com a literatura nacional, colocando em cena a voz de grupos historicamente condenados à mudez. A partir da configuração desse sujeito nordestino embrenhado na floresta, podemos encontrar outro ângulo de visão, o do pobre e escravizado imigrante que contribui para a recuperação da história dos seringais amazônicos, ofertando-nos a apreensão do aspecto cultural, suprimido em diversas narrativas frente à grandiosidade da floresta. 


\section{CONSIDERAÇÕES FINAIS}

Zeca-Dama é um cearense pobre e homicida, que, fugindo da polícia, embarcou para o Amazonas com o intento de ganhar dinheiro. Em um regime de trabalho escravizante, embrenhado na floresta, isolado do mundo, tendo apenas alguns companheiros de trabalho ao seu redor, ele se vê cada dia mais distante de sua terra natal, abandonando a ilusão de regressar e, por conseguinte, de reencontrar sua família. É a voz desse nordestino que Erasmo Linhares escolheu para narrar os contos que integram a trilogia "Três estórias da terra". Ao fazer isso, o autor amazonense construiu um narrador alinhado com as transformações que a literatura brasileira vinha vivenciando, ao mesmo tempo em que contribuiu, no cenário local, com uma revisão das formas narrativas que eram, extensivamente, empregadas na região.

Sob o primeiro aspecto, foi possível perceber que Zeca-Dama, por sua constituição, oferece ao leitor um ponto de vista que o distancia da tradição patriarcal que imperou, durante muito tempo, na produção literária brasileira, construindo sua fala a partir de situações vistas e vivenciadas por ele as quais, anteriormente, seriam relatadas por um narrador em terceira pessoa. Sua voz, enquanto pobre, migrante e escravizado, somente pôde ser considerada como relevante a partir do processo de reestruturação que foi vivenciado pela produção nacional iniciado na década de 1960. Em relação ao segundo aspecto, entendemos que é possível pensar a revisão das formas narrativas que foram empregadas na literatura amazonense até meados do século XX como um reflexo das mudanças que vinham ocorrendo no cenário nacional e com as quais o autor de $O$ tocador de charamela estava alinhado. Sob esse prisma, para pensar a prosa de Linhares, no cenário amazonense, foi necessário fazê-lo a partir de um olhar que também abarcasse a esfera nacional.

Ao final deste estudo, esperamos, a partir da análise da figura de Zeca-Dama, primeiramente, ter oferecido uma leitura da trilogia Três estórias da terra, que tenha englobado o espaço delineado por essa publicação tanto no cenário literário local quanto no nacional. E, em segundo lugar, almejamos ter contribuído para dar visibilidade e promover a discussão da produção literária de Erasmo Linhares, a qual, mesmo décadas após a sua publicação, segue pouco explorada. 


\section{REFERÊNCIAS}

ADORNO, T. W. A posição do narrador no romance contemporâneo. In: ADORNO, T. W. Notas de Literatura I. Tradução e apresentação de Jorge M. B. de Almeida. São Paulo; Duas Cidades: Ed. 34, 2003. p. 55-63

BENJAMIN, W. Experiência e pobreza. In: BENJAMIN, W. Magia e técnica. Arte e política: ensaios sobre literatura e história da cultura. Tradução de Sérgio Paulo Rouanet. 7. ed. São Paulo: Brasiliense, 1994. p. 114-119

BENJAMIN, W. O narrador. Considerações sobre a obra de Nikolai Leskov. In: BENJAMIN, W. Magia e técnica. Arte e política: ensaios sobre literatura e história da cultura. Tradução de Sérgio Paulo Rouanet. 7. ed. São Paulo: Brasiliense, 1994. p. 197- 221

DALCASTAGNÈ, R. Uma voz ao sol: representação e legitimidade na narrativa brasileira contemporânea. Estudos de Literatura Brasileira Contemporânea, no 20. Brasília, julho/agosto de 2002, p. 33-77.

ENGRÁCIO, A. Poetas e prosadores contemporâneos do Amazonas. Manaus: Universidade do Amazonas, 1994.

GINZBURG, J. O narrador na literatura brasileira contemporânea. Tintas. Quaderni di letterature iberiche e iberoamericane, n. 2, 2012. p. 199-221

LINHARES, E. O tocador de charamela. Manaus: Edições Rio Mar, 1979.

RUAS, L. Prefácio. In: LINHARES, E. O tocador de charamela. Manaus: Edições Rio Mar, 1979. p. 11-14

PICCININ, F. O (complexo) exercício de narrar e os formatos múltiplos: para pensar a narrativa no contemporâneo. In: PICCININ, F.; SOSTER; D. de A. (Org.). Narrativas comunicacionais complexificadas. Santa Cruz do Sul: EDUNISC, 2012. p. 68-88.

SANTOS, J. B. dos. Uma leitura de Três estórias da terra, de Erasmo Linhares. In: OLIVEIRA, R. do P. S. de. (Org.) A literatura no Amazonas: 1954-2010 - Volume II. Rio de Janeiro: Letra Capital, 2018. p. 188- 211

SCHOLES, R.; KELLOG, R. A natureza da narrativa. São Paulo: McGraw-Hill, 1977.

SILVA, A. M. L. da. Representações da natureza na ficção amazonense. 2008. 194f. Tese de Doutorado. Programa de Pós-Graduação em Letras: Estudos Literários, Universidade Federal de Minas Gerais (UFMG), Belo Horizonte, 2008. 